\title{
Heart irradiation reduces microvascular density and accumulation of HSPA1 in mice
}

\author{
Anna Walaszczyk ${ }^{1}$ - Katarzyna Szołtysek ${ }^{1}$ Karol Jelonek ${ }^{1} \cdot J^{\prime}$ Konna Polańska ${ }^{2}$ Wolfgang Dörr ${ }^{3,4}$ • \\ Julia Haagen $^{3}$ Piotr Widłak ${ }^{1}$ - Dorota Gabryśs ${ }^{5}$ (D)
}

Received: 3 May 2017 / Accepted: 19 September 2017 / Published online: 23 October 2017

(c) The Author(s) 2017. This article is an open access publication.

\begin{abstract}
Purpose Improvement of radiotherapy techniques reduces the exposure of normal tissues to ionizing radiation. However, the risk of radiation-related late effects remains elevated. In the present study, we investigated long-term effects of radiation on heart muscle morphology.

Materials and methods We established a mouse model to study microvascular density (MVD), deposition of collagen fibers, and changes in accumulation of heat shock $70 \mathrm{kDa}$ protein 1 (HSPA 1 ) in irradiated heart tissue. Hearts of $\mathrm{C} 57 \mathrm{BL} / 6$ mice received a single dose of $\mathrm{X}$-ray radiation in the range $0.2-16 \mathrm{~Gy}$. Analyses were performed 20, 40, and 60 weeks after irradiation.
\end{abstract}

Electronic supplementary material The online version of this article (https://doi.org/10.1007/s00066-017-1220-z) contains supplementary material, which is available to authorized users.

Dorota Gabryś, PhD, MD

gabdorka@gmail.com

1 Center for Translational Research and Molecular Biology of Cancer, Maria Skłodowska-Curie Memorial Cancer Center and Institute of Oncology Gliwice Branch, Wybrzeże Armii Krajowej 15, 44-101 Gliwice, Poland

2 Silesian University of Technology, Gliwice, Poland

3 Department of Radiotherapy and Radiooncology, Medical Faculty Carl Gustav Carus, University of Technology, Dresden, Germany

4 Department of Radiation Oncology, Applied and Translational Radiobiology (ATRAB), Medical University Vienna, Vienna, Austria

5 Department of Radiotherapy, Maria Skłodowska-Curie Memorial Cancer Center and Institute of Oncology Gliwice Branch, Wybrzeże Armii Krajowej 15, 44-101 Gliwice, Poland
Results Reduction in MD was revealed as a long-term effect observed 20-60 weeks after irradiation. Moreover, a significant and dose-dependent increase in accumulation of HSPA1, both cytoplasmic and nuclear, was observed in heart tissues collected 20 weeks after irradiation. We also noticed an increase in collagen deposition in hearts treated with higher doses.

Conclusions This study shows that some changes induced by radiation in the heart tissue, such as reduction in microvessel density, increase in collagen deposition, and accumulation of HSPA1, are observed as long-term effects which might be associated with late radiation cardiotoxicity.

Keywords Cardiotoxicity · Adverse effects . Cardiovascular system - HSPA70-1 heat-shock proteins . Myocardial ischemia

\section{Herzbestrahlung reduziert die mikrovaskuläre Dichte und Akkumulation von HSPA1 in Mäusen}

\section{Zusammenfassung}

Zielsetzung Die Verbesserung der Strahlentherapietechnik reduziert die Exposition von normalen Geweben mit ionisierender Strahlung. Allerdings bleibt das Risiko strahlenbedingter Spätfolgen erhöht. In der vorliegenden Studie untersuchten wir die Langzeitwirkung einer Strahlenexposition des Herzmuskels in Bezug auf morphologische Veränderungen.

Material und Methoden Wir haben ein Mausmodell etabliert, um die mikrovaskuläre Dichte (MVD), Ablagerung von Kollagenfasern und Veränderungen der Akkumulation von 70kDa-Hitzeschockprotein 1 (HSPA1) in bestrahltem Herzgewebe zu untersuchen. Männliche C57BL/6- 
Mäuse erhielten in Einzeldosen Röntgenstrahlen zwischen 0,2-16 Gy. Die Herzen wurden für die Analyse 20, 40 und 60 Wochen nach der Bestrahlung entnommen.

Ergebnisse Als Langzeitwirkung 20-60 Wochen nach der Bestrahlung zeigte sich eine Reduktion der MVD. Weiterhin zeigte sich 20 Wochen nach Bestrahlung eine signifikante und dosisabhängige Akkumulationszunahme von HSPA1, sowohl zytoplasmatisch als auch nukleär. Auch wurde eine Kollagenablagerung in Herzgeweben festgestellt, die mit höheren Dosen behandelt wurden.

Schlussfolgerung Diese Studie zeigt, dass die Bestrahlung zu Veränderungen, wie Verringerung der MVD, Zunahme der Kollagenablagerung und Akkumulation von HSPA1 im Herzgewebe, führt, die mit einer späten Strahlenkardiotoxizität assoziiert sein können.

Schlüsselwörter Kardiotoxizität · Nebenwirkungen ·

Kardiovaskuläres System · HSPA70-1

Hitzeschockproteine $\cdot$ Myokardiale Ischämie

Cancer and heart diseases are the major cause of death worldwide. Over $50 \%$ of cancer patients are treated with radiotherapy. Modern radiotherapy techniques applied in recent decades contribute to increasing long-term survival of cancer patients. However, long-term effects of successful anticancer treatment involve an increase in late adverse events. Radiotherapy, if applied in the thoracic region, represents a potential risk factor for the cardiovascular system. Cardiovascular damage has been reported as a long-term adverse/side effect event in breast cancer survivors previously treated with radiotherapy. The risk of cardiovascular diseases is correlated with tumor location and was found to be significantly increased following irradiation of the left breast compared to the right and the rate of ischemic heart disease was significantly increased, even with doses $<2 \mathrm{~Gy}$ [1-4]. Therefore, experimental animal and cellular studies are necessary, not only for a correct extrapolation of risk estimations, but also for the evaluation of biological mechanisms identification of potential biomarkers of the risk, and the development of therapeutic countermeasures [5].

In order to explore mechanisms behind the pathogenesis of early and late radiation-related alterations in the microcirculation of the heart, the European Consortium called CARDIORISK was formed in 2008 and the following work was performed within its framework. This project addressed both macro- and microvascular radiation effects after local irradiation of the heart, with a special focus on the radiation response in the low-dose range [6].

Radiation-induced heart disease includes a wide spectrum of cardiac pathologies, including pericarditis, cardiomyopathy, myocardial fibrosis, valvular disorders, coronary artery disease, and conduction abnormalities. Factors enhancing the risk of cardiotoxic effects of radiation are both treatment-related and endogenous. On the list related to treatment are the following: high dose, large irradiated volume, concomitant chemotherapy-especially the use of anthracyclines. Among endogenous factors increasing risk of treatment side effects are the following: young age of patients, overweight, atherosclerosis, and hypertension $[7,8]$. Endothelial cells are the primary target for ionizing radiation across the myocardial vasculature. The main acute effect of radiation is accumulation of lymphocytes and as a consequence inflammation. Inflammation induces contraction of blood vessels in the heart muscle. This may lead to remodeling of the cytoskeleton and formation of gaps between adjacent endothelial cells [9]. Myocardial ischemia is dominant among late effects and is usually accompanied with increased collagen synthesis and fibrosis $[10,11]$.

The 70-kDa heat shock protein (HSP70) family constitutes one of the most conserved protein families $[12,13]$. HSPA1 (also known as HSP70-1, HSP72, or HSP70i) is the main stress-induced HSP and among the first and the most prominent proteins which are found in stressed cells. Therefore, this protein is often used as a general marker of a stress response [14]. Heat shock proteins (HSPs) represent chaperones that protect cells against a variety of stresses. They are involved in the regulation of the immune responses including antigen processing and cross-presentation [14]. Expression and accumulation of heat shock proteins in heart tissue could be induced by inflammation, hypoxia, chemotherapy, hyperthermia, and oxidative stress [15-20]. Stress-induced upregulation of HSPs promotes cell (including cardiomyocytes) survival [12, 21]. Although HSP are widely analyzed, we still lack information regarding HSP changes in the heart after exposure to ionizing radiation.

Currently, only several radiobiological models relevant for assessment of cardiotoxic effects of ionizing radiation are available. One of the models that considers the complex and long-term nature of radiotherapy-related damage involved in heart failure uses mouse hearts from animals irradiated in vivo. In the present study, we investigated longterm effects of radiation on heart muscle morphology. We analyzed microvascular density (MVD), deposition of collagen fibers, and changes in accumulation of stress-inducible heat shock $70 \mathrm{kDa}$ protein 1 (HSPA1) in irradiated mouse heart tissue.

\section{Materials and methods}

\section{Animals and irradiation procedure}

The experimental procedures have been reported in detail elsewhere [22]. In brief, male C57BL/6 mice (Charles 
River Laboratories, Research Models and Services, Germany $\mathrm{GmbH}$ ) aged $8 \pm 1$ weeks were immobilized and locally irradiated using a YXLON MG325 device (Yxlon International X-ray $\mathrm{GmbH}$, Germany) operated at $200 \mathrm{kV}$, with a tube current of $20 \mathrm{~mA}$ and a beam filter of $0.6 \mathrm{~cm}$ $\mathrm{Cu}$, resulting in a dose rate of $0.8045 \mathrm{~Gy} \cdot \mathrm{min}^{-1}$. Single local heart doses of $0.2,2,8$, or 16 Gy were applied. The exact position of the heart was assessed by radiography before irradiation. The whole heart was included in the irradiated volume, plus about $20 \%$ of the lung, but excluded the liver and other organs, as previously reported [23]. Age-matched, sham irradiated ( $0 \mathrm{~Gy}$ ) animals were included in the study. Animals were irradiated in Dresden, shipped to Gliwice 1-2 months after irradiation and maintained on a regular chow diet (1324 TPF standard diets, Spezialfutter $\mathrm{GmbH}$ \& Co. KG, Germany) and tap water ad libitum. The environmental conditions were as follows: temperature of $21 \pm$ $2{ }^{\circ} \mathrm{C}$, humidity of $55 \pm 10 \%$, illuminance of $350 \mathrm{~lx}$ (at bench level) and a 12:12 light: dark cycle. Animals were housed in $207 \times 140 \times 365 \mathrm{~mm}$ cages (type IIL, BIOSCAPE, Germany). Each treatment group comprised 5 mice.

\section{Tissue preparation}

After 20, 40, and 60 weeks following irradiation the animals were sacrificed by cervical dislocation, the hearts were excised, divided into 3 pieces on the horizontal axis (apex, ventricles, and atria). From each heart, the ventricles were cryoembedded for immunohistochemistry, the apex was frozen for gene expression analysis, and the atria were fixed with $37 \%$ formaldehyde. For analysis of ultrastructure using electron microscopy, a small piece of the left ventricle was fixed in buffered $3 \%$ glutaraldehyde in cacodylate buffer (unpublished results). Cross-sections of the ventricles were cut in a horizontal plane $(7 \mu \mathrm{m})$. Of these sections, 5 to 6 were analyzed per heart, each representing a different part of the ventricle. The average number of images analyzed per heart was 23. In total, we analyzed about 600 images to evaluate microvessel density. To analyze collagen fiber deposition, we established a similar pattern. In total, about 470 images were analyzed. To evaluate the HSPA1, we analyzed the positive area (estimated as a percentage of whole tissue section); two complete cross-sections were inspected for each mouse and several images were analyzed to cover each cross-section. The protocol was approved by the Committee on the Ethics of Animal Experiments of Landesdirektion Dresden (file no. 24-1968.1-11/2009-10; Germany).

\section{Immunohistochemistry}

An anti-CD31 antibody (1:50, Becton and Dickinson) was used to visualize cardiac vasculature in the ventricles. An
anti-HSP70i antibody (1:50, Stressgen SPA-810) was used to evaluate the expression of HSPA1 protein. The frozen sections were air-dried. Endogenous peroxidase activity was blocked with $0.3 \%$ hydrogen peroxide in methanol for $30 \mathrm{~min}$. Endogenous biotin was suppressed with the avidin/biotin kit (15 min each; DAKO, ITK Diagnostics BV, Uithoorn, The Netherlands). Protein block serum-free (DAKO) was used to minimize unspecific binding of the antibody $(20 \mathrm{~min})$, then slides were incubated overnight with primary antibodies (diluted 1:50 with 1\% bovine serum albumin [BSA]/phosphate-buffered saline [PBS]) at $4{ }^{\circ} \mathrm{C}$. The slides were then rinsed with PBS and subsequently incubated with biotinylated secondary antibodies (45 min). After rising with PBS, the signal was amplified with avidin-biotin complex (ABC) reagent (Vectastain ABC Kit). Antibody reactivity was detected using horseradish peroxidase (HRP)-conjugated biotin-avidin complexes (Vector Laboratories, Burlingame, CA, USA) and developed with diaminobenzidine (DAB) solution (Sigma). All sections were processed identically within one experiment. For microvascular density analysis tissue slides were photographed with Nikon Eclipse $80 \mathrm{i}, 40 \times$ objective, five random fields per slide were taken into consideration.

\section{Collagen deposition}

The trichrome method was used for detection of collagen fibers in the heart muscle preparations as described by Gomori [24]. Using this method, cell nuclei are stained in dark blue or black, muscle fibers are stained in red, while the connective tissue, primarily collagen, is presented in green. Based on Gomorie trichrome staining, collagen was determined in heart ventricles. Slides were fixed with $37 \%$ formaldehyde, incubated with Bouin's reagent (Sigma-Aldrich HT-10-1-128, $15 \mathrm{~min}, 56{ }^{\circ} \mathrm{C}$,) and, after washing with tap water, stained with Weigert's iron hematoxylin (Sigma-Aldrich HT10-7, HT10-9). After that, slides were stained with LG (Gomori one-step trichrome [light green] procedure) reagent (Sigma-Aldrich HT10-316) then washed for $1 \mathrm{~min}$ in $0.5 \%$ acetic acid, dehydrated (50-100\% ethyl alcohol) and mounted in DPX mounting medium for histology (Sigma-Aldrich). Slides were analyzed with Nicon Eclipse 80i, $20 \times$ objective; five random fields were photographed per slide.

\section{Statistical analysis}

All technical repeats (average 23 replicates) were combined for each experimental group. The Shapiro-Wilk test was applied to verify the hypotheses on normality of distribution across experimental groups [25]. Homogeneity of dispersion was tested by Brown-Forsythe test [26]. Equality of median values was checked with the use of Mann-Whitney 
U test [27]. Hodges-Lehmann minimum distance estimator and its 95\% confidence interval (CI) were used for estimation of the shift between distributions [28]. Results with $p<$ 0.05 were considered as statistically significant.

\section{Results}

\section{Vessel density}

Staining for CD31, an antigen specific for endothelial cells, was used to estimate microvascular density (MVD). The results are presented in Fig. 1. In the group of animals analyzed 20 weeks after irradiation with $16 \mathrm{~Gy}$, we observed a statistically significant decrease of MVD. In animals analyzed 40 weeks after irradiation, statistically significant reduction of MVD was observed after 2 and $8 \mathrm{~Gy}$, while a similar trend was observed after $16 \mathrm{~Gy}(p=0.055)$. In animals analyzed 60 weeks after irradiation, a statistically significant reduction of MVD was found after irradiation with 2,8 , and $16 \mathrm{~Gy}$. In the animals irradiated with a low dose $(0.2 \mathrm{~Gy})$, no changes in microvascular density were observed at any follow-up period.

\section{Collagen deposition}

A statistically significant increase in collagen deposition was observed in heart tissue of mice analyzed 20 weeks after irradiation with $8 \mathrm{~Gy}$. Moreover, a similar trend was observed for animals analyzed 40 and 60 weeks after irradiation with 16 Gy (Fig. 2).

\section{HSPA1 protein accumulation}

A statistically significant dose-dependent increase in accumulation of HSPA1 (staining-positive area in relation to the control) was observed in heart tissues analyzed 20 weeks after irradiation (Fig. 3). At 40 weeks, there seems to be a trend for a dose response, although not significant. In contrast, 60 weeks after irradiation similar levels of HSPA1 were observed in both irradiated and control animals.

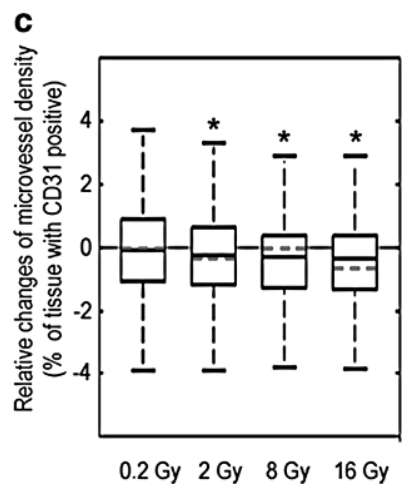

Fig. 1 Changes in microvascular density. The figure illustrates relative changes in the microvascular density (\% of area positive for anti-CD31; ratio irradiated animals and control) in hearts irradiated with doses ranging from $0.2-16 \mathrm{~Gy}$, relative to age-matched not irradiated controls. Samples were analyzed at 20 (a), 40 (b), 60 (c) weeks after irradiation. Boxplots show maximum and minimum, upper and lower quartiles, and median; horizontal dashed line represents arithmetic average; asterisks indicate significant differences $(p<0.05)$ between control and irradiated animals
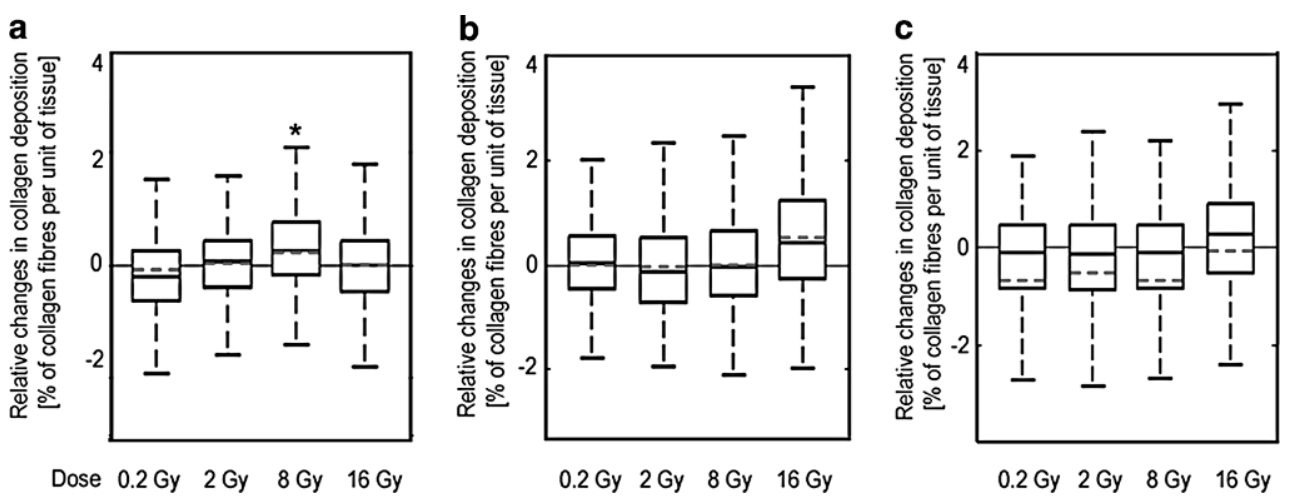

Fig. 2 Collagen fiber deposition. The figure shows relative changes of tissue areas positive for trichrome staining (\% of heart area; ratio irradiated animals and control). Samples were analyzed at 20 (a), 40 (b), or 60 (c) weeks after irradiation. Boxplots show maximum and minimum, upper and lower quartiles, and median; horizontal dashed line represents arithmetic average; asterisks indicate significant differences $(p<0.05)$ between control and irradiated animals 

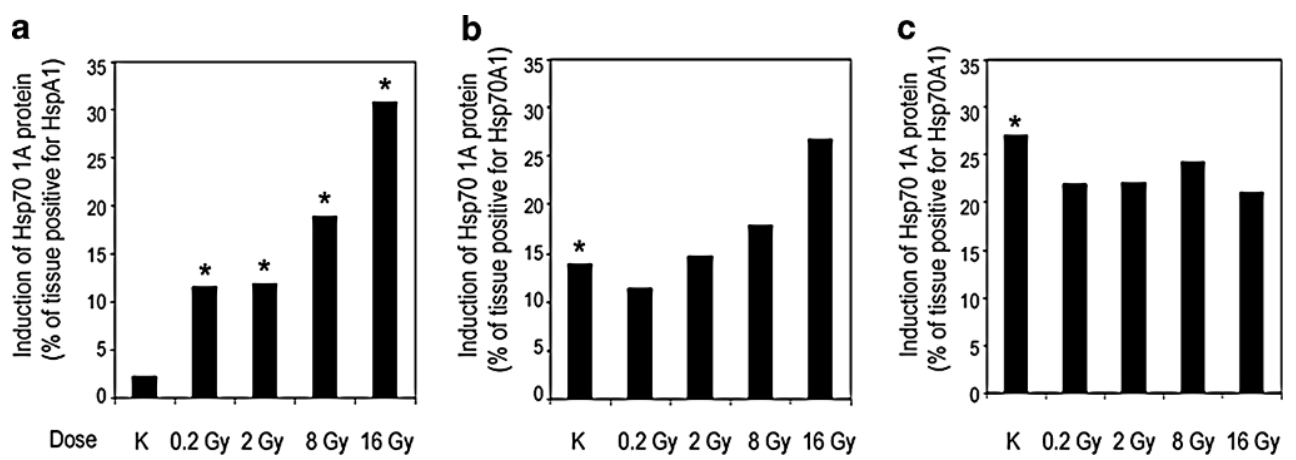

Fig. 3 Changes in Hsp70A1 protein accumulation. The figure illustrates changes in the relative accumulation of HspA1 (\% of area positive). Samples were analyzed 20 (a), 40 (b), or 60 (c) weeks after irradiation. Bars show the median value; asterisks indicate significant differences $(p<$ 0.05 ) between irradiated animals and control (a), or between 48- and 68-week-old control animals with respect to control 28-week-old control mice $(\mathbf{b}, \mathbf{c})$

However, it should be noted that a clear age-related increase in HSPA1 protein levels was detected in nonirradiated control animals (Fig. 3). Moreover, cellular localization of HSPA1 was analyzed in hearts of animals exposed to radiation using a fluorescence-labeled anti-HSPA1 antibody and DAPI counterstaining (see Supplementary Fig. S1). We found expression of HSPA1 in both the cytoplasm and the nucleus at 20 weeks after exposure to $16 \mathrm{~Gy}$. This was in marked contrast to cardiac cells of animals exposed to hyperthermia (unpublished data), where a primarily nuclear localization of HSPA1 was observed $18 \mathrm{~h}$ after the heat shock (Supp. Fig. S1).

\section{Discussion}

Improvement of radiotherapy techniques reduces the exposure of normal tissues to ionizing radiation. In the case of the heart, it considerably reduces the risk of early cardiovascular complications [29]. However, the risk of late effects of radiation remains elevated even after decades [30]. Endothelial cells comprise only a minor fraction of cardiac cells, but they are critical for radiation-induced damage [31]. In our study, reduction in microvascular density was revealed as a long-term effect observed 20-60 weeks after irradiation. These observations are consistent with results obtained by other laboratories forming the CARDIORISK consortium. Gabriels et al. [32] showed reduction of MVD in a heart 20 and 40 weeks after irradiation of ApoE (-/-) mice with doses of 8 and $16 \mathrm{~Gy}$. Seemann et al. [33] reported decrease in MVD after 40 and 60 weeks following irradiation with the doses of 8 or $16 \mathrm{~Gy}$ in C57/BL6 mice.

On the other hand, no clear differences were detected in the MVD 16 weeks after irradiation in C57BL/6 mice by Azimzadeh et al. [34]. Small quantitative differences between these data and our results are most likely a consequence of a different heart area subjected to analysis, or different staining or analytical procedures. In our study, the measurement of MVD was performed in the ventricles of the heart in a cross section, while the group of Seemann and Azimzadeh analyzed only the left ventricle. These types of heart tissue changes may induce or intensify an existing heart disease, which eventually may have an impact on the function of the heart [35]. In fact, our results and those from others confirm that ionizing radiation reduces vascular density irrespective of the subvolume of the heart analyzed and differences in treatment protocols.

The reduction in the density of vessels likely results from endothelial cell damage induced by ionizing radiation. As a consequence, local hypoxia may be induced, leading to damage of both small vessels and the myocardium. One of the effects of myocardial ischemia is progressive fibrosis [36, 37].

Therefore, one may expect progressive fibrosis especially in the case of high doses and after a long follow-up. However, our results do not confirm this hypothesis. Similar results were obtained in other analyses within the CARDIORISK consortium. After exposure to low doses of radiation $(0.2$ or $2 \mathrm{~Gy})$, there was a significant increase in the density of collagen fibers only in ApoE (-/-), but not in C57BL/6 mice [23]. In another study, the presence of collagen was elevated for C57BL/6 mice after 40 weeks of exposure to 8 or $16 \mathrm{~Gy}$. However, even 60 weeks after exposure to a dose of 2 or $8 \mathrm{~Gy}$, these changes were only seen in a small volume (2-5\%) of the heart [33]. Difference in the response between the two mice strains may be related to the fact that accumulation of lipid deposits caused by malfunction of lipid metabolism in $\mathrm{ApoE}^{----}$mice leads to oxidative processes, which could be intensified by irradiation, causing significant collagen formation. Perhaps in wild-type mice, irradiation without an additional risk factor is not sufficient to cause increased collagen deposition.

In the present study, involvement of HSPA1 in long-term effects of heart irradiation was documented. Accumulation of HSPA1 protein was increased 20 weeks after irradiation in a dose-dependent manner. Longer follow-up (40 or 
60 weeks after irradiation) revealed increased HSPA1 protein accumulation in both control and irradiated animals, which indicates that changes induced by radiation per se may not be detected in older animals. Actually, it is known that aging induces structural and functional changes in the heart and vasculature. Furthermore, in elderly individuals, cardiac mechanisms responsible for protection from injury as well as injury repair itself become increasingly defective, thus, leading to accentuated adverse remodeling and increased dysfunction (reviewed in [38]).

It is noteworthy that HSPA1 accumulated in response to ionizing radiation showed ubiquitous cellular localization (both nuclear and cytoplasmic), which was in contrast to nuclear localization of this protein accumulated in "acute" response to hyperthermia.

Several lines of evidence indicated a role of HSPA1 in response to ionizing radiation and heart damage. In general, overexpression of HSPA1 is radioprotective and increases long-term viability (reviewed in [39]). Increased expression of HSPA1 was observed in endothelial cells isolated from C57BL/6 mice 16 weeks after X-ray irradiation, which was accompanied by increased levels of oxidized low density lipoprotein (oxLDL) and impairment of NO production [34]. Moreover, expression of HSPA1 increase during cardiac hypertrophy in mice, and its overexpression protects the heart against damaging effects of ischemia [40, 41]. In humans with heart failure, plasma concentrations of HSPA1 increase gradually with the progression of disease stages; therefore, HSPA1 could be used as a potential screening biomarker for the early diagnosis of heart failure [40]. A plethora of HSPA1 functions involves activation of proinflammatory reaction or decreasing it in the cases of over-activation of the immune system. Thus, in the context of "oxi-inflamm-aging", HSPA1 was proposed as one of the possible regulators of this process (reviewed in [42]). In humans, the serum concentration of HSPA1 decreases with age in a normal population while increased serum levels are frequently associated with frail health and inflammation [43].

In ICR-CD1 and Balb/C female mice, the 120-weekold group showed higher HSPA1 levels in the heart than the 82-week-old group, and these levels were similar to those found in 40-week-old animals [44]. Here we observed markedly higher level of HSPA1 in 48- to 68-week-old C57BL/6 male mice in comparison to 28 -week-old animals (Fig. 3). The results of these studies cannot be compared directly because of differences in strain, age, and sex of the animals (ICR/CD-1 are more prone to inflammation than C57BL/6 mice, and the expression of cardiac HSPA1 could be different in female and male mice due to variable levels of estrogen $[45,46])$. Nevertheless, both reports documented age-related increase in the cardiac HSPA1 level. Elevated levels of HSPA1 were found in human myocardial tissues in case of ischemia, following coronary artery bypass grafting or aortic cross-clamp surgery, and in patients with coronary artery disease (a protective role of HSPA1 has been suggested) [47]. In general, because HSPs have been considered as a potential therapeutic target for cardiac disease, it is important to further assess the role of HSPA1 in acute and chronic cardiac disease [48].

\section{Conclusion}

The present study shows that some of the changes induced by radiation in the heart tissue, such as a reduction in microvessel density, increased collagen deposition, and accumulation of HSPA1, are observed as long-term effects which might be associated with late radiation cardiotoxicity. Better knowledge of the effects of radiation and the mechanisms of its formation may allow us to more effectively fight its cardiovascular consequences.

Acknowledgements The research received funding from the European Atomic Energy Community's Seventh Framework Program (FP7/2007-2011) under the grant agreement no. 211403 (CARDIORISK) and from the National Science Center, Poland, under grant no. N-402-685640. We also thank Professor Monika Pietrowska and Dr Marta Gawin for critical reading of the manuscript, as well as Professor Wiesława Widłak and Mr. Marek Chadalski for help in the analysis of cellular localization of HSPA1.

Conflict of interest A. Walaszczyk, K. Szołtysek, K. Jelonek, J. Polańska, W. Dörr, J. Haagen, P. Widłak and D. Gabryś declare that they have no competing interests.

Open Access This article is distributed under the terms of the Creative Commons Attribution 4.0 International License (http:// creativecommons.org/licenses/by/4.0/), which permits unrestricted use, distribution, and reproduction in any medium, provided you give appropriate credit to the original author(s) and the source, provide a link to the Creative Commons license, and indicate if changes were made.

\section{References}

1. Marmagkiolis K, Finch W, Tsitlakidou D, Josephs T, Iliescu C, Best JF, Yang EH (2016) Radiation toxicity to the cardiovascular system. Curr Oncol Rep 18(3):15. https://doi.org/10.1007/s11912016-0502-4

2. Darby SC, Ewertz M, McGale P, Bennet AM, Blom-Goldman U, Bronnum D, Correa C, Cutter D, Gagliardi G, Gigante B, Jensen MB, Nisbet A, Peto R, Rahimi K, Taylor C, Hall P (2013) Risk of ischemic heart disease in women after radiotherapy for breast cancer. N Engl J Med 368(11):987-998. https://doi.org/10.1056/ NEJMoa1209825

3. Trott KR (2016) Some considerations for future research into the risks of radiation-induced cardiovascular diseases. Strahlenther Onkol 192(11):747-749. https://doi.org/10.1007/s00066-0161030-8

4. Taylor CW, Wang Z, Macaulay E, Jagsi R, Duane F, Darby SC (2015) Exposure of the heart in breast cancer radiation therapy: A systematic review of heart doses published during 2003 to 2013. Int 
J Radiat Oncol Biol Phys 93(4):845-853. https://doi.org/10.1016/j. ijrobp.2015.07.2292

5. Tapio S (2016) Pathology and biology of radiation-induced cardiac disease. J Radiat Res 57(5):439-448. https://doi.org/10.1093/ jrr/rrw064

6. Cardiorisk (2017) Cardiorisk. http://www.cardiorisk.eu/. Accessed 10 Aug 2017

7. Boerma M, Hauer-Jensen M (2010) Potential targets for intervention in radiation-induced heart disease. Curr Drug Targets 11(11):1405-1412

8. Andratschke N, Maurer J, Molls M, Trott KR (2011) Late radiationinduced heart disease after radiotherapy. Clinical importance, radiobiological mechanisms and strategies of prevention. Radiother Oncol 100(2):160-166. https://doi.org/10.1016/j.radonc.2010.08.010

9. Gabrys D, Greco O, Patel G, Prise KM, Tozer GM, Kanthou C (2007) Radiation effects on the cytoskeleton of endothelial cells and endothelial monolayer permeability. Int J Radiat Oncol Biol Phys 69(5):1553-1562. https://doi.org/10.1016/j.ijrobp.2007.08.039

10. Darby SC, Cutter DJ, Boerma M, Constine LS, Fajardo LF, Kodama K, Mabuchi K, Marks LB, Mettler FA, Pierce LJ, Trott KR, Yeh ET, Shore RE (2010) Radiation-related heart disease: Current knowledge and future prospects. Int J Radiat Oncol Biol Phys 76(3):656-665. https://doi.org/10.1016/j.ijrobp.2009.09.064

11. Taunk NK, Haffty BG, Kostis JB, Goyal S (2015) Radiation-induced heart disease: Pathologic abnormalities and putative mechanisms. Front Oncol 5:39. https://doi.org/10.3389/fonc.2015.00039

12. Radons J (2016) The human HSP70 family of chaperones: Where do we stand? Cell Stress Chaperones 21(3):379-404. https://doi. org/10.1007/s12192-016-0676-6

13. Finka A, Sood V, Quadroni M, Rios Pde L, Goloubinoff $P$ (2015) Quantitative proteomics of heat-treated human cells show an across-the-board mild depletion of housekeeping proteins to massively accumulate few HSPs. Cell Stress Chaperones 20(4):605-620. https://doi.org/10.1007/s12192-015-0583-2

14. Multhoff G, Hightower LE (2011) Distinguishing integral and receptor-bound heat shock protein 70 (Hsp70) on the cell surface by Hsp70-specific antibodies. Cell Stress Chaperones 16(3):251-255. https://doi.org/10.1007/s12192-010-0247-1

15. Polla BS (1988) A role for heat shock proteins in inflammation? Immunol Today 9(5):134-137. https://doi.org/10.1016/01675699(88)91199-1

16. Efthymiou CA, Mocanu MM, de Belleroche J, Wells DJ, Latchmann DS, Yellon DM (2004) Heat shock protein 27 protects the heart against myocardial infarction. Basic Res Cardiol 99(6):392-394. https://doi.org/10.1007/s00395-004-0483-6

17. Nishizawa J, Nakai A, Higashi T, Tanabe M, Nomoto S, Matsuda K, Ban T, Nagata K (1996) Reperfusion causes significant activation of heat shock transcription factor 1 in ischemic rat heart. Circulation 94(9):2185-2192

18. Kee HJ, Eom GH, Joung H, Shin S, Kim JR, Cho YK, Choe N, Sim BW, Jo D, Jeong MH, Kim KK, Seo JS, Kook H (2008) Activation of histone deacetylase 2 by inducible heat shock protein 70 in cardiac hypertrophy. Circ Res 103(11):1259-1269. https://doi.org/10. 1161/01.res.0000338570.27156.84

19. Henninger C, Huelsenbeck S, Wenzel P, Brand M, Huelsenbeck J, Schad A, Fritz G (2015) Chronic heart damage following doxorubicin treatment is alleviated by lovastatin. Pharmacol Res 91:47-56. https://doi.org/10.1016/j.phrs.2014.11.003

20. Dehbi M, Baturcam E, Eldali A, Ahmed M, Kwaasi A, Chishti MA, Bouchama A (2010) Hsp-72, a candidate prognostic indicator of heatstroke. Cell Stress Chaperones 15(5):593-603. https://doi.org/ 10.1007/s12192-010-0172-3

21. Zhao Y, Wang W, Qian L (2007) Hsp70 may protect cardiomyocytes from stress-induced injury by inhibiting Fas-mediated apoptosis. Cell Stress Chaperones 12(1):83-95
22. Patties I, Haagen J, Dorr W, Hildebrandt G, Glasow A (2015) Late inflammatory and thrombotic changes in irradiated hearts of C57BL/6 wild-type and atherosclerosis-prone ApoE-deficient mice. Strahlenther Onkol 191(2):172-179. https://doi.org/10.1007/ s00066-014-0745-7

23. Monceau V, Meziani L, Strup-Perrot C, Morel E, Schmidt M, Haagen J, Escoubet B, Dorr W, Vozenin MC (2013) Enhanced sensitivity to low dose irradiation of ApoE-/- mice mediated by early proinflammatory profile and delayed activation of the TGFbetal cascade involved in fibrogenesis. PLOS ONE 8(2):e57052. https://doi. org/10.1371/journal.pone.0057052

24. Gomori G (1950) A rapid one-step trichrome stain. Am J Clin Pathol 20(7):661-664

25. Shapiro SS, Wilk MB (1965) An analysis of variance test for normality (complete samples). Biometrika 52(3-4):591-611. https:// doi.org/10.1093/biomet/52.3-4.591

26. Brown MB, Forsythe AB (1974) Robust tests for equality of variances. J Am Stat Assoc 69:364-367

27. Mann HB, Whitney DR (1947) On a test of whether one of two random variables is stochastically larger than the other. Ann Math Stat 18(1):50-60

28. Hodges JL, Lehmann E (2005) Basic concepts of probability and statistics. Classics in applied mathematics. SIAM, Philadelphia. https://doi.org/10.1137/1.9780898719123

29. Violet JA, Harmer C (2004) Breast cancer: improving outcome following adjuvant radiotherapy. Br J Radiol 77(922):811-820. https:// doi.org/10.1259/bjr/44576710

30. Aleman BM, van den Belt-Dusebout AW, Klokman WJ, Van't Veer MB, Bartelink H, van Leeuwen FE (2003) Long-term cause-specific mortality of patients treated for Hodgkin's disease. J Clin Oncol 21(18):3431-3439. https://doi.org/10.1200/jco.2003.07.131

31. Jelonek K, Walaszczyk A, Gabrys D, Pietrowska M, Kanthou C, Widlak P (2011) Cardiac endothelial cells isolated from mouse heart - a novel model for radiobiology. Acta Biochim Pol 58(3): 397-404

32. Gabriels K, Hoving S, Seemann I, Visser NL, Gijbels MJ, Pol JF, Daemen MJ, Stewart FA, Heeneman S (2012) Local heart irradiation of $\mathrm{ApoE}(-/-)$ mice induces microvascular and endocardial damage and accelerates coronary atherosclerosis. Radiother Oncol 105(3):358-364. https://doi.org/10.1016/j.radonc.2012.08.002

33. Seemann I, Gabriels K, Visser NL, Hoving S, te Poele JA, Pol JF, Gijbels MJ, Janssen BJ, van Leeuwen FW, Daemen MJ, Heeneman $S$, Stewart FA (2012) Irradiation induced modest changes in murine cardiac function despite progressive structural damage to the myocardium and microvasculature. Radiother Oncol 103(2):143-150. https://doi.org/10.1016/j.radonc.2011.10.011

34. Azimzadeh O, Sievert W, Sarioglu H, Merl-Pham J, Yentrapalli R, Bakshi MV, Janik D, Ueffing M, Atkinson MJ, Multhoff G, Tapio S (2015) Integrative Proteomics and targeted transcriptomics analyses in cardiac Endothelial cells unravel mechanisms of long-term radiation-induced vascular dysfunction. J Proteome Res 14(2):1203-1219. https://doi.org/10.1021/pr501141b

35. Stewart FA (2012) Mechanisms and dose-response relationships for radiation-induced cardiovascular disease. Ann ICRP 41(3-4):72-79. https://doi.org/10.1016/j.icrp.2012.06.031

36. Kania G, Blyszczuk P, Eriksson U (2009) Mechanisms of cardiac fibrosis in inflammatory heart disease. Trends Cardiovasc Med 19(8):247-252. https://doi.org/10.1016/j.tcm.2010.02.005

37. Stewart FA, Hoving S, Russell NS (2010) Vascular damage as an underlying mechanism of cardiac and cerebral toxicity in irradiated cancer patients. Radiat Res 174(6):865-869. https://doi.org/10. $1667 / \mathrm{rr} 1862.1$

38. Strait JB, Lakatta EG (2012) Aging-associated cardiovascular changes and their relationship to heart failure. Heart Fail Clin 8(1):143-164. https://doi.org/10.1016/j.hfc.2011.08.011 
39. Calini V, Urani C, Camatini M (2003) Overexpression of HSP70 is induced by ionizing radiation in $\mathrm{C} 3 \mathrm{H} 10 \mathrm{~T} 1 / 2$ cells and protects from DNA damage. Toxicol In Vitro 17(5):561-566

40. Li Z, Song Y, Xing R, Yu H, Zhang Y, Li Z, Gao W (2013) Heat shock protein 70 acts as a potential biomarker for early diagnosis of heart failure. PLOS ONE 8(7):e67964. https://doi.org/10.1371/ journal.pone. 0067964

41. Trost SU, Omens JH, Karlon WJ, Meyer M, Mestril R, Covell JW, Dillmann WH (1998) Protection against myocardial dysfunction after a brief ischemic period in transgenic mice expressing inducible heat shock protein 70. J Clin Invest 101(4):855-862. https://doi.org/ 10.1172/jci265

42. Martinez de Toda I, De la Fuente M (2015) The role of Hsp70 in oxi-inflamm-aging and its use as a potential biomarker of lifespan. Biogerontology 16(6):709-721. https://doi.org/10.1007/s10522015-9607-7

43. Njemini R, Bautmans I, Onyema OO, Van Puyvelde K, Demanet C, Mets T (2011) Circulating heat shock protein 70 in health, aging and disease. Bmc Immunol 12:24. https://doi.org/10.1186/14712172-12-24
44. de Toda IM, Vida C, Ortega E, De La Fuente M (2016) Hsp70 basal levels, a tissue marker of the rate of aging and longevity in mice. Exp Gerontol 84:21-28. https://doi.org/10.1016/j.exger.2016. 08.013

45. Nikodemova M, Watters JJ (2011) Outbred ICR/CD1 mice display more severe neuroinflammation mediated by microglial TLR4/CD14 activation than inbred C57B1/6 mice. Neuroscience 190:67-74. https://doi.org/10.1016/j.neuroscience.2011.06.006

46. Voss MR, Stallone JN, Li M, Cornelussen RN, Knuefermann P, Knowlton AA (2003) Gender differences in the expression of heat shock proteins: The effect of estrogen. Am J Physiol Heart Circ Physiol 285(2):H687-H692. https://doi.org/10.1152/ajpheart. 01000.2002

47. de Jong PR, Schadenberg AW, Jansen NJ, Prakken BJ (2009) Hsp70 and cardiac surgery: Molecular chaperone and inflammatory regulator with compartmentalized effects. Cell Stress Chaperones 14(2):117-131. https://doi.org/10.1007/s12192-008-0066-9

48. Bernardo BC, Weeks KL, Patterson NL, McMullen JR (2016) HSP70: Therapeutic potential in acute and chronic cardiac disease settings. Future Med Chem 8(18):2177-2183. https://doi.org/10. 4155/fmc-2016-0192 